\title{
Serum Concentrations of Betatrophin and Its Association with Indirect Indices of Insulin Resistance and Beta Cell Function in Women with Polycystic Ovary Syndrome
}

\author{
Agnieszka Adamska, ${ }^{1}$ Agnieszka Lebkowska, ${ }^{1}$ Matgorzata Jacewicz, ${ }^{1}$ Anna Krentowska, \\ Justyna Hryniewicka, ${ }^{1}$ Slawomir Wołczyński, ${ }^{2}$ Maria Górska, ${ }^{1}$ and Irina Kowalska ${ }^{1}$ \\ ${ }^{1}$ Department of Endocrinology, Diabetology and Internal Medicine, Medical University of Białystok, Białystok, Poland \\ ${ }^{2}$ Department of Reproduction and Gynecological Endocrinology, Medical University of Białystok, Białystok, Poland \\ Correspondence should be addressed to Agnieszka Adamska; ak001@wp.pl
}

Received 21 January 2017; Revised 27 April 2017; Accepted 4 May 2017; Published 18 June 2017

Academic Editor: Amelie Bonnefond

Copyright ( 2017 Agnieszka Adamska et al. This is an open access article distributed under the Creative Commons Attribution License, which permits unrestricted use, distribution, and reproduction in any medium, provided the original work is properly cited.

\begin{abstract}
Introduction. Data underline the role of betatrophin in glucose homeostasis. Polycystic ovary syndrome (PCOS) is characterized by insulin resistance (IR). The aim of our study was to investigate the relationship of serum betatrophin concentrations with indirect indices of IR and insulin secretion in women with PCOS, compared to the control group. Methods. The study group comprised 43 women with PCOS and 16 controls. IR was assessed by HOMA-IR and Matsuda index. Insulin secretion was evaluated with HOMA-B. An oral glucose tolerance test (OGTT) with estimation of serum betatrophin concentrations was performed. Results. Glucose load resulted in an increase in serum betatrophin concentrations in the control group $(p=0.02)$. Serum betatrophin concentrations at $120 \mathrm{~min}$ of OGTT were lower in women with PCOS than in the control group $(p=0.02)$. We observed positive correlations between baseline serum betatrophin concentrations and HOMA-IR $(r=0.39, p=0.008)$, negative correlations with Matsuda index $(r=-0.31, p=0.004)$, and a positive relationship with HOMA-B $(r=0.38, p=0.01)$ in women with PCOS. Multiple regression analysis revealed that HOMA-B $(\beta=0.47, p=0.001)$ was an independent factor connected to serum betatrophin levels in PCOS. Conclusions. Serum concentrations of betatrophin are connected with insulin resistance and beta cell function and did not change after glucose load in women with PCOS.
\end{abstract}

\section{Introduction}

Polycystic ovary syndrome (PCOS) is a frequent endocrinopathy which affects about $5-10 \%$ of reproductive-aged women [1]. Patients with PCOS may present a variety of reproductive and metabolic disturbances, including oligo/ anovulation, polycystic ovary in the ultrasound, and hyperandrogenism, as well as insulin resistance [2]. Moreover, it has been shown that beta cell dysfunction is present in PCOS individuals [3]. It is widely known that insulin resistance and impaired beta cell function play a crucial role in the pathogenesis of type 2 diabetes mellitus (T2D). Therefore, women with PCOS, who often show both aforementioned traits, are at higher risk of impaired glucose tolerance, T2D, as well as disturbances in lipid profile [4].
Betatrophin, also called refeeding-induced fat and liver protein (RIFL) [5], lipasin [6], or atypical angiopoietin-like protein 8 (ANGPLT8) [7], is a $22 \mathrm{kDa}$ hormone. In mice, betatrophin is produced by the liver, white adipose tissue (WAT), and brown adipose tissue (BAT), while in humans, it is mainly produced by the liver [6]. It has been shown that betatrophin has a dual role: it affects glucose homeostasis and lipid metabolism [8-12].

In a mouse model of insulin resistance induced by insulin receptor antagonist S961, hepatic and WAT overexpression of betatrophin was observed. This was accompanied by beta cell replication, followed by improved glucose tolerance [8]. The results obtained by these authors suggest that betatrophin can exert a promoting role on beta cell replication. However, these data were not confirmed by Gusarova 
et al. [13]. They reported that ANGPTL8 ${ }^{-1-}$ mice with insulin resistance induced by a high-fat diet or insulin receptor antagonist S961 had normal beta cell expansion. This indicates that betatrophin is not necessary for beta cell proliferation. Interestingly, in their experiment, a significant reduction of triglyceride (TG) in $\mathrm{ANGPTL8}^{-/-}$mice in comparison to wild-type mice was observed [13].

In humans, the role of betatrophin in glucose metabolism is unclear. Studies that investigated its action in both healthy subjects and patients with diabetes have brought conflicting results so far. Some researchers showed increased levels of serum betatrophin in T2D [14, 15], type 1 diabetes mellitus (T1D) [16], and gestational diabetes [17], whereas other data report decreased serum betatrophin concentrations in obese individuals and T2D patients [11].

Interestingly, it has also been demonstrated that there are no significant differences in serum betatrophin levels between nondiabetic and T2D patients and between the lean and the morbidly obese patients [12]. On the other hand, a comprehensive meta-analysis by $\mathrm{Li}$ et al. suggested that circulating betatrophin levels in T2D nonobese patients are higher than those in the nondiabetic control group [9]. Moreover, recent studies showed that plasma concentrations of metabolic markers, for example, betatrophin, as well as hepatocyte growth factor and nesfatin, are elevated in drugnaïve prediabetic and T2D patients in comparison to normoglycemic subjects $[18,19]$. It has also been observed that serum betatrophin concentration positively correlated with $\mathrm{HbA1c}$ and fasting plasma glucose in the group of patients with diabetes, prediabetic state, and metabolic syndrome [19] and with fasting plasma glucose and HOMA-IR in T2D and nondiabetic subjects [20].

Some data indicate that serum betatrophin concentrations are positively connected with the level of C-peptide in obese nondiabetic subjects [15]. However, this observation was not present in T2D patients [15]. In other studies, serum betatrophin concentrations inversely correlated with the increment of C-peptide in the glucagon stimulation test in T2D patients [21]. This might indicate that the increase in serum betatrophin concentrations is a result of insulin resistance observed in obese nondiabetic subjects.

Apart from its role in glucose homeostasis, betatrophin has an impact on lipid metabolism. In experimental data, betatrophin suppressed adipose triglyceride lipase activity and increased TG accumulation in hepatocytes, adipocytes, and beta cells [22]. In the fasted state, similar serum TG levels in ANGPTL8 ${ }^{-/-}$mice and wild-type animals were noticed. However, lower serum TG concentrations in response to refeeding in mice lacking the betatrophin gene have been observed [23]. Moreover, starvation decreased betatrophin expression in BAT and WAT [6]. This could suggest that betatrophin influences lipid homeostasis in the refeeding state.

As it was mentioned earlier, betatrophin could be involved in glucose and lipid metabolism, which is often impaired in women with PCOS. Therefore, the aim of the present study was to investigate serum betatrophin concentrations after glucose load and its relationship with indirect indices of insulin resistance and insulin secretion in women with PCOS in comparison to the healthy controls.

\section{Materials and Methods}

2.1. Subjects. The study group consisted of 59 women-43 patients with PCOS and 16 healthy controls matched for BMI and age. The diagnosis of PCOS was made according to the 2003 Rotterdam ESHRE/ASRM PCOS Consensus Workshop Group diagnostic criteria [24]. We defined PCOS by the presence of at least two out of three criteria: clinical and/or biochemical hyperandrogenism, oligo/anovulation, and polycystic ovaries ( $>12$ follicles measuring $2-9 \mathrm{~mm}$ in diameter or ovarian volume $>10 \mathrm{ml}$ in at least one ovary) [24]. Women with PCOS were recruited from the outpatient clinic of the Department of Endocrinology, Diabetology and Internal Medicine, Medical University of Bialystok.

Clinical examination, anthropometric measurements, body fat assessment by bioelectrical impedance analysis, oral glucose tolerance test (OGTT) with 75 grams of glucose load, and ultrasonography of ovaries were performed as previously described [2]. Lipids, hormonal profiles (LH, FSH, total testosterone, and PRL), and serum betatrophin concentrations at the baseline and at $120 \mathrm{~min}$ of OGTT were estimated. Exclusion criteria included the following: morbid obesity, cardiovascular disease, and hyperlipidemia; other causes of irregular menstrual cycles and/or androgen excess (i.e., hyperprolactinemia, Cushing's syndrome, late-onset congenital adrenal hyperplasia, or other diseases of the thyroid, adrenal glands, pregnancy, and breastfeeding); type 1 or type 2 diabetes; chronic or acute infection (within the previous 30 days); any other serious medical problem, hormonal contraception, and/or antiandrogen therapy (within the previous 6 months); and the use of medications for obesity, hyperglycemia, dyslipidemia, or hypertension. All participants were nonsmokers. All analyses were carried out after an overnight fast. Studies were performed in the PCOS group 3-5 days after spontaneous menses or independently of cycle phase in the presence of amenorrhea and in regularly cycling women during the early follicular phase (3rd-5th day) of their menstrual cycle. All subjects gave written informed consent. The study protocol was approved by the Ethics Committee of Medical University of Bialystok, Poland, and was concordant with the Declaration of Helsinki.

2.2. Biochemical Analyses. Plasma glucose level was measured immediately by the enzymatic reference method with hexokinase (Cobas c111, Roche Diagnostic Ltd., Switzerland). Serum insulin concentration was assayed by immunoradiometric method (DIAsource ImmunoAssays S.A., Belgium). The minimum detectable concentration was $1 \mu \mathrm{IU} / \mathrm{ml}$ and the intra-assay and interassay coefficients of variation (CVs) were below $2.2 \%$ and $6.5 \%$, respectively. In this method, human and animal proinsulins present no cross-reactions.

Serum total cholesterol, HDL-cholesterol, and TG were assessed by the enzymatic methods using commercial kits produced by ANALCO-GBG, Poland. Serum LDL cholesterol was calculated according to Friedewald's formula.

Serum luteinizing hormone (LH) (sensitivity $0.2 \mathrm{mIU} / \mathrm{ml}$; intra-assay CV 3.9\%, interassay CV 3.4\%), follicle-stimulating hormone (FSH) (sensitivity $0.1 \mathrm{mIU} / \mathrm{ml}$; intra-assay $\mathrm{CV}$ $2.0 \%$, interassay CV $4.4 \%$ ), and serum prolactin (sensitivity 
$0.35 \mathrm{ng} / \mathrm{ml}$; intra-assay CV 3.3\%, interassay CV 4.5\%) were measured by the immunoradiometric method (DIAsource ImmunoAssays S.A., Belgium). Serum total testosterone (sensitivity $0.05 \mathrm{ng} / \mathrm{dl}$; intra-assay $\mathrm{CV} 4.6 \%$, interassay $\mathrm{CV}$ $6.2 \%$ ) was measured by the radioimmunoassay (DIAsource ImmunoAssays S.A., Belgium). Free-androgen index (FAI) was calculated as serum total testosterone $(\mathrm{nmol} / \mathrm{l}) \times 100 /$ SHBG (nmol/l) ratio [25].

Serum betatrophin level was detected by enzyme-linked immunosorbent assays using commercially available reagents (USCN Life Science Inc., Wuhan, China); the detection range was $0.156-10 \mathrm{ng} / \mathrm{ml}$ and the sensitivity was less than $0.057 \mathrm{ng} / \mathrm{ml}$. Intra- and interassay coefficients of variation were under $10 \%$ and $12 \%$, respectively. $\Delta$ betatrophin was calculated as the difference in betatrophin between $0 \mathrm{~min}$ and $120 \mathrm{~min}$ of OGTT.

\subsection{Calculations. Consider as following:}

(1) The homeostasis model assessment insulin resistance (HOMA-IR) was calculated according to the formula in [26]:

$$
\frac{\mathrm{FPI} \times \mathrm{FPG}}{22.5}
$$

(2) Whole-body insulin sensitivity was calculated by Matsuda index according to the formula in [27]:

$$
\frac{10000}{\sqrt{(\mathrm{FPG} \times \mathrm{FPI}) \times(\mathrm{MPG} \times \mathrm{MPI})}} .
$$

(3) Islet beta cell function was evaluated by homeostasis model assessment $\beta$ cell function (HOMA-B) according to the formula in [26]:

$$
\frac{20 \times \text { FPI }}{\text { FPG }-3.5}
$$

where FPI is fasting plasma insulin $(\mu \mathrm{IU} / \mathrm{ml})$, FPG is fasting plasma glucose $(\mathrm{mmol} / \mathrm{l}), \mathrm{MPG}$ is mean plasma glucose during OGTT $(\mathrm{mmol} / \mathrm{l})$, and MPI is mean plasma insulin during OGTT $(\mu \mathrm{IU} / \mathrm{ml})$.

2.4. Statistical Analysis. The statistics were performed with STATISTICA 10.0 software. The differences between the groups were evaluated with nonparametric Mann-Whitney $U$ test. The relationships between variables were evaluated using Spearman's rank correlation and multiple linear

\begin{tabular}{|c|c|c|}
\hline & $\begin{array}{l}\text { Control group } \\
\quad(n=16)\end{array}$ & $\begin{array}{l}\text { PCOS } \\
(n=43)\end{array}$ \\
\hline Age (years) & $24.3 \pm 4.1$ & $25.3 \pm 4.5$ \\
\hline BMI $\left(\mathrm{kg} / \mathrm{m}^{2}\right)$ & $22.8 \pm 3.0$ & $24.5 \pm 3.1$ \\
\hline Waist circumference $(\mathrm{cm})$ & $80.3 \pm 7.9$ & $85.2 \pm 10.7$ \\
\hline Hip circumference $(\mathrm{cm})$ & $99.7 \pm 7.3$ & $101.6 \pm 8.4$ \\
\hline FFM (kg) & $45.5 \pm 5.1$ & $46.7 \pm 6.0$ \\
\hline FM (kg) & $18.6 \pm 6.6$ & $22.6 \pm 7.2^{*}$ \\
\hline LDL cholesterol (mg/dl) & $86.9 \pm 20.4$ & $100.5 \pm 40.9$ \\
\hline $\mathrm{TG}(\mathrm{mg} / \mathrm{dl})$ & $70.4 \pm 17.1$ & $78.7 \pm 39.7$ \\
\hline Glucose $0^{\prime}$ OGTT (mg/dl) & $89 \pm 6.8$ & $88.2 \pm 6.6$ \\
\hline Glucose 30' OGTT (mg/dl) & $128.5 \pm 24.6$ & $145 \pm 28.5^{*}$ \\
\hline Glucose $60^{\prime}$ OGTT (mg/dl) & $97 \pm 22.7$ & $123.5 \pm 35.8^{*}$ \\
\hline Glucose $120^{\prime}$ OGTT (mg/dl) & $92 \pm 15.6$ & $95.7 \pm 21.6$ \\
\hline Insulin $0^{\prime}$ OGTT $(\mu \mathrm{IU} / \mathrm{ml})$ & $11.9 \pm 5.5$ & $11.5 \pm 4.7$ \\
\hline Insulin $30^{\prime}$ OGTT $(\mu \mathrm{IU} / \mathrm{ml})$ & $63.7 \pm 28.5$ & $89.3 \pm 56.7$ \\
\hline Insulin $60^{\prime}$ OGTT $(\mu \mathrm{IU} / \mathrm{ml})$ & $58.6 \pm 49.2$ & $84.4 \pm 51.5^{*}$ \\
\hline Insulin $120^{\prime}$ OGTT $(\mu \mathrm{IU} / \mathrm{ml})$ & $35.8 \pm 16.9$ & $56.4 \pm 49.6$ \\
\hline HOMA-IR & $2.6 \pm 1.2$ & $2.5 \pm 1.0$ \\
\hline HOMA-B & $175.1 \pm 80.7$ & $193 \pm 186.3$ \\
\hline Matsuda index & $5.37 \pm 1.7$ & $4.8 \pm 2.1$ \\
\hline $\begin{array}{l}\text { Follicle-stimulating } \\
\text { hormone (IU/l) }\end{array}$ & $5.8 \pm 2.8$ & $4.5 \pm 1.4$ \\
\hline Luteinizing hormone (IU/l) & $3.7 \pm 1.3$ & $6.3 \pm 3.9^{*}$ \\
\hline Total testosterone (ng/ml) & $0.5 \pm 0.2$ & $0.8 \pm 0.4^{*}$ \\
\hline SHBG (nmol/l) & $48.0 \pm 19.1$ & $45.4 \pm 22.6$ \\
\hline FAI & $4.3 \pm 2.2$ & $8.4 \pm 5.9^{*}$ \\
\hline Prolactin (ng/ml) & $14.4 \pm 6.8$ & $15.2 \pm 9.0$ \\
\hline Betatrophin $0^{\prime}(\mathrm{ng} / \mathrm{ml})$ & $0.92 \pm 0.35$ & $0.85 \pm 0.33$ \\
\hline Betatrophin $120^{\prime}(\mathrm{ng} / \mathrm{ml})$ & $1.15 \pm 0.42^{\#}$ & $0.88 \pm 0.32^{*}$ \\
\hline \multicolumn{3}{|c|}{$\begin{array}{l}\text { Data are presented as mean } \pm \mathrm{SD} \text {. Differences between the groups are } \\
\text { derived from nonparametric Mann-Whitney } U \text { test. BMI: body mass } \\
\text { index; TG: triglycerides; FM: fat mass; FFM: fat-free mass; OGTT: oral } \\
\text { glucose tolerance test; HOMA-IR: homeostasis model assessment insulin } \\
\text { resistance; HOMA-B: homeostasis model assessment } \beta \text { cell function; FAI: } \\
\text { free-androgen index; SHBG: sex hormone-binding globulin; }{ }^{*} p<0.05 \text { in } \\
\text { PCOS women versus control group; }{ }^{*} p<0.05 \text { versus the baseline state. }\end{array}$} \\
\hline
\end{tabular}

TABLE 1: Clinical and biochemical characteristics of the studied groups.

regression analysis. The level of significance was accepted at $p<0.05$.

\section{Results}

The clinical and biochemical characteristics of the studied groups are presented in Table 1. The PCOS and control women did not differ in age, anthropometric indices, plasma lipid concentrations, baseline plasma glucose concentrations, baseline serum insulin concentrations, HOMA-IR, Matsuda index, and HOMA-B (all $p>0.05$ ) (Table 1). Women with PCOS had significantly elevated serum LH $(p=0.01)$, total testosterone concentrations $(p=0.009)$, and FAI $(p=0.0009)$ in comparison to the control group (Table 1). 


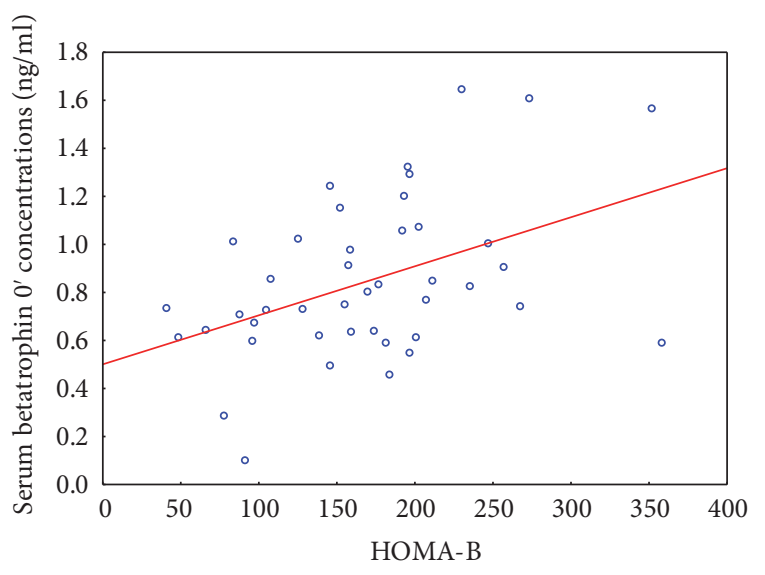

(a)

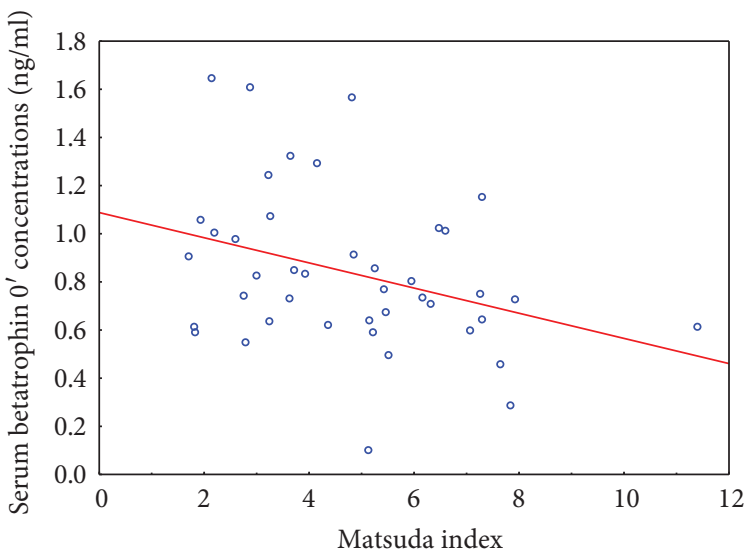

(b)

Figure 1: Correlation between serum betatrophin $0^{\prime}$ concentrations and HOMA-B $(r=0.38, p=0.01)(\mathrm{a})$ and Matsuda index $(r=-0.31$, $p=0.004)(b)$ in women with PCOS.

In the PCOS group, higher plasma concentrations of glucose at $30^{\prime}(p=0.03)$ and $60^{\prime}(p=0.01)$ of OGTT, as well as higher serum insulin concentrations at $60^{\prime}(p=0.02)$ of OGTT, in comparison to those in the control group were observed (Table 1).

Baseline serum betatrophin concentrations did not differ between the studied groups $(p=0.7)$. Glucose load resulted in an increase in serum betatrophin concentrations only in the control group $(p=0.02)$. In consequence, serum betatrophin concentrations at $120 \mathrm{~min}$ of OGTT were lower in women with PCOS in comparison to the control group $(p=0.02)$ (Table 1).

We found a positive correlation between baseline serum betatrophin concentrations and baseline serum insulin concentration $(r=0.42, p=0.004)$, only in women with PCOS.

We found a negative relationship between $\Delta$ betatrophin and serum total testosterone concentration in the entire group $(r=-0.32, p=0.01)$.

We subsequently examined the relationship between baseline serum betatrophin and indirect indices of insulin resistance, as well as beta cell function in the studied groups. We observed a positive correlation of baseline betatrophin concentrations with HOMA-IR $(r=0.39, p=0.008)$, a negative correlation with Matsuda index $(r=-0.31, p=0.004)$, and a positive relationship with HOMA-B $(r=0.38$, $p=0.01$ ) (Figure 1), only in women with PCOS.

In the next step, we created a linear regression model for betatrophin as a dependent variable. The model that best predicted betatrophin in patients with PCOS included HOMA-B as an independent variable ( $p=0.001, \beta=0.47)$. This model explained $22.3 \%$ of the variability in betatrophin concentrations $\left(R^{2}=0.223\right)$.

\section{Discussion}

The main observation of the present study is the different responses to glucose load in PCOS women in comparison to the healthy women. The glucose load did not cause any increase in serum betatrophin concentrations during OGTT in the PCOS group, contrary to what was observed in the control group. Additionally, we observed relations between serum betatrophin and indirect measures of insulin resistance, as well as HOMA-B, only in the PCOS group. We also found a negative relationship between $\Delta$ betatrophin during OGTT and serum total testosterone concentration in the entire group.

The important observation of the present study is the lack of an increase in serum betatrophin after glucose load during OGTT in the PCOS group, as it was observed in controls. There is no straightforward explanation of this phenomenon. In several murine studies, it was shown that fasting is a negative regulator of betatrophin mRNA expression in BAT, WAT, and liver $[6,7,28]$. In humans, one study examined the impact of meals on serum betatrophin concentrations. The authors evaluated 12 nonobese nondiabetic subjects and observed a statistically significant increase in serum betatrophin concentrations 2 hours after a mixed meal containing carbohydrate, protein, and fat [29]. This indicates that its concentrations in healthy subjects rise in response to food intake, as we did not notice the increase in serum betatrophin concentrations during OGTT in women with PCOS in comparison to the control group. Therefore, we can speculate that its disturbances in this group of patients could first appear in the postprandial state.

Other factors contributing to changes in betatrophin concentrations during glucose load still require identifying. In the present study, we observed an increased level of total testosterone in women with PCOS and an inverse correlation between $\Delta$ betatrophin and total testosterone levels in the entire group. Therefore, we can hypothesize that elevated total testosterone concentrations might influence serum betatrophin concentrations in response to glucose load during OGTT in the PCOS group. Similarly, Calan et al. showed that serum betatrophin is related to free-testosterone concentrations in PCOS [30]. Additionally, we can hypothesize that inappropriate response in releasing betatrophin after glucose load could lead to the development of glucose intolerance in women with PCOS.

Another observation of the present study is a finding that baseline serum betatrophin concentrations negatively correlated with indirect indices of insulin sensitivity, for example, 
Matsuda index, and positively with HOMA-IR and HOMA-B only in patients with PCOS. Moreover, in the linear regression analysis, we observed that baseline serum betatrophin concentration was strongly connected with HOMA-B. Therefore, we can assume that serum betatrophin concentrations depend on insulin secretion from beta cells in women with PCOS. As it was mentioned in the Introduction, it has been shown that serum betatrophin concentration positively correlated with C-peptide and HOMA-IR in obese nondiabetic subjects but not in T2D patients [15]. It could be possible that during the development of insulin resistance, betatrophin is not sufficient to compensate for an increased demand for insulin, as it was observed in T2D [14].

Our results are consistent with those of other researchers who showed a positive correlation between serum betatrophin concentration and HOMA-IR in women with PCOS [30] and in the group consisting of patients with T2D and prediabetes and in the control group [20]. Qu et al. also observed that fasting serum betatrophin concentration positively correlated with HOMA-IR only in women with PCOS [31], but did not estimate HOMA-B and Matsuda index. Additionally, Sahin et al. found that serum betatrophin level variability in the PCOS women was explained by homocysteine, HOMA-IR, and androstenedione levels [32]. Erol et al. reported an elevated serum betatrophin concentration in the PCOS women in comparison to the control group, although they did not evaluate HOMA-IR, Matsuda index, or HOMA-B [33].

Contradictory results have been recently reported by other researchers, who found a negative correlation between fasting serum betatrophin concentration and HOMA-IR [34-36]. Song et al. also observed a negative relationship between serum betatrophin concentration and HOMA-B in the PCOS women [34]. Different results obtained by the cited authors could be derived from differences in anthropometrical measurements of the studied groups. We examined Caucasian women with mean BMI $24.5 \pm 3.1 \mathrm{~kg} / \mathrm{m}^{2}$, whereas Song et al. studied Chinese women with mean BMI $25.4 \pm 5.0 \mathrm{~kg} / \mathrm{m}^{2}$ [34]. Additionally, our group of women with PCOS was younger $(25.3 \pm 4.5 \mathrm{yr}$ versus 28.9 $\pm 4.9 \mathrm{yr})$. As betatrophin action could reflect a compensatory response in insulin resistant state and is proposed as a marker of insulin resistance, it is important to take these indices into consideration while comparing the results of different studies [20]. Moreover, we cannot exclude the influence of ethnic origin on serum betatrophin concentrations and different phenotypes of PCOS included in the quoted studies. However, the role of this hormone in the pathogenesis of insulin resistance in PCOS women is not established yet.

The main limitation of the present study is the relatively small sample size, especially in the control group.

\section{Conclusions}

On the basis of the obtained results, we concluded that serum concentrations of betatrophin are connected with insulin resistance and beta cell function and did not change after glucose load in women with PCOS.

\section{Abbreviations}

ANGPLT8: Atypical angiopoietin-like protein 8

BAT: $\quad$ Brown adipose tissue

BMI: $\quad$ Body mass index

CV: $\quad$ Coefficient of variation

FAI: $\quad$ Free-androgen index

FFM: $\quad$ Fat-free mass

FM: $\quad$ Fat mass

FSH: $\quad$ Follicle-stimulating hormone

HOMA-B: Homeostasis model assessment $\beta$ cell function

HOMA-IR: Homeostasis model assessment insulin resistance

IR: Insulin resistance

LH: $\quad$ Luteinizing hormone

OGTT: Oral glucose tolerance test

PCOS: $\quad$ Polycystic ovary syndrome

RIFL: $\quad$ Refeeding-induced fat and liver protein

SHBG: $\quad$ Sex hormone-binding globulin

T1D: $\quad$ Type 1 diabetes mellitus

T2D: $\quad$ Type 2 diabetes mellitus

TG: $\quad$ Triglycerides

WAT: White adipose tissue.

\section{Conflicts of Interest}

The authors declare that they have no conflict of interest.

\section{Acknowledgments}

This study was funded by a grant from the Medical University of Bialystok (Grant no. N/ST/ZB/15/010/1150).

\section{References}

[1] E. Diamanti-Kandarakis and A. Dunaif, "Insulin resistance and the polycystic ovary syndrome revisited: an update on mechanisms and implications," Endocrine Reviews, vol. 33, no. 6, pp. 981-1030, 2012.

[2] I. Kowalska, M. Straczkowski, A. Nikolajuk et al., "Serum visfatin in relation to insulin resistance and markers of hyperandrogenism in lean and obese women with polycystic ovary syndrome," Human Reproduction, vol. 22, no. 7, pp. 18241829, 2007.

[3] A. Dunaif and D. T. Finegood, "Beta-cell dysfunction independent of obesity and glucose intolerance in the polycystic ovary syndrome," The Journal of Clinical Endocrinology and Metabolism, vol. 81, no. 3, pp. 942-947, 1996.

[4] S. A. Arslanian, V. D. Lewy, and K. Danadian, "Glucose intolerance in obese adolescents with polycystic ovary syndrome: roles of insulin resistance and beta-cell dysfunction and risk of cardiovascular disease," The Journal of Clinical Endocrinology and Metabolism, vol. 86, no. 1, pp. 66-71, 2001.

[5] G. Ren, J. Y. Kim, and C. M. Smas, "Identification of RIFL, a novel adipocyte-enriched insulin target gene with a role in lipid metabolism," American Journal of Physiology. Endocrinology and Metabolism, vol. 303, no. 3, pp. E334-E351, 2012.

[6] R. Zhang, "Lipasin, a novel nutritionally-regulated liverenriched factor that regulates serum triglyceride levels," Biochemical Biophysical Research Communications, vol. 424, no. 4, pp. 786-792, 2012. 
[7] F. Quagliarini, Y. Wang, J. Kozlitina et al., "Atypical angiopoietin-like protein that regulates ANGPTL3," Proceedings of the National Academy of Sciences of the United States of America, vol. 109, no. 48, pp. 19751-19756, 2012.

[8] P. Yi, J. S. Park, and D. A. Melton, "Betatrophin: a hormone that controls pancreatic $\beta$ cell proliferation," Cell, vol. 153, no. 4, pp. 747-758, 2013.

[9] S. Li, D. Liu, L. Li et al., "Circulating betatrophin in patients with type 2 diabetes: a meta-analysis," Journal of Diabetes Research, vol. 2016, Article ID 6194750, p. 9, 2016.

[10] H. Hu, W. Sun, S. Yu et al., "Increased circulating levels of betatrophin in newly diagnosed type 2 diabetic patients," Diabetes Care, vol. 37, no. 10, pp. 2718-2722, 2014.

[11] J. Gomez-Ambrosi, E. Pascual, V. Catalan et al., "Circulating betatrophin concentrations are decreased in human obesity and type 2 diabetes," The Journal of Clinical Endocrinology and Metabolism, vol. 99, no. 10, pp. E2004-E2009, 2014.

[12] A. Fenzl, B. K. Itariu, L. Kosi et al., "Circulating betatrophin correlates with atherogenic lipid profiles but not with glucose and insulin levels in insulin-resistant individuals," Diabetologia, vol. 57, no. 6, pp. 1204-1208, 2014.

[13] V. Gusarova, C. A. Alexa, E. Na et al., "ANGPTL8/betatrophin does not control pancreatic beta cell expansion," Cell, vol. 159, no. 3, pp. 691-696, 2014.

[14] M. Abu-Farha, J. Abubaker, I. Al-Khairi et al., "Higher plasma betatrophin/ANGPTL8 level in type 2 diabetes subjects does not correlate with blood glucose or insulin resistance," Scientific Reports, vol. 5, p. 10949, 2015.

[15] M. Abu-Farha, J. Abubaker, F. Noronha et al., "Lack of associations between betatrophin/ANGPTL8 level and C-peptide in type 2 diabetic subjects," Cardiovascular Diabetology, vol. 14, no. 1, p. 112, 2015.

[16] D. Espes, J. Lau, and P. O. Carlsson, "Increased circulating levels of betatrophin in individuals with long-standing type 1 diabetes," Diabetologia, vol. 57, no. 1, pp. 50-53, 2014.

[17] L. K. Trebotic, P. Klimek, A. Thomas et al., "Circulating betatrophin is strongly increased in pregnancy and gestational diabetes mellitus," PloS One, vol. 10, no. 9, article e0136701, 2015.

[18] A. Akour, V. Kasabri, N. Boulatova et al., "Levels of metabolic markers in drug-naive prediabetic and type 2 diabetic patients," Acta Diabetologica, vol. 54, no. 2, pp. 163-170, 2017.

[19] A. Al-Rawashdeh, V. Kasabri, N. Bulatova et al., "The correlation between plasma levels of oxytocin and betatrophin in non-diabetic and diabetic metabolic syndrome patients: a cross sectional study from Jordan," Diabetes and Metabolic Syndrome, vol. 11, no. 1, pp. 59-67, 2017.

[20] X. Chen, P. Lu, W. He et al., "Circulating betatrophin levels are increased in patients with type 2 diabetes and associated with insulin resistance," The Journal of Clinical Endocrinology and Metabolism, vol. 100, no. 1, pp. E96-100, 2015.

[21] S. Tokumoto, Y. Hamamoto, K. Fujimoto et al., "Correlation of circulating betatrophin concentrations with insulin secretion capacity, evaluated by glucagon stimulation tests," Diabetic Medicine, vol. 32, no. 5, pp. 653-656, 2015.

[22] Y. Zhang, S. Li, W. Donelan et al., "Angiopoietin-like protein 8 (betatrophin) is a stress-response protein that down-regulates expression of adipocyte triglyceride lipase," Biochimica et Biophysica Acta, vol. 1861, no. 2, pp. 130-137, 2016.

[23] Y. Wang, F. Quagliarini, V. Gusarova et al., "Mice lacking ANGPTL8 (betatrophin) manifest disrupted triglyceride metabolism without impaired glucose homeostasis,"
Proceedings of the National Academy of Sciences of the United States of America, vol. 110, no. 40, pp. 16109-16114, 2013.

[24] Rotterdam ESHRE/ASRM-Sponsored PCOS Consensus Workshop Group, "Revised 2003 consensus on diagnostic criteria and long-term health risks related to polycystic ovary syndrome," Fertility and Sterility, vol. 81, no. 1, pp. 19-25, 2004.

[25] A. Vermeulen, L. Verdonck, and J. M. Kaufman, “A critical evaluation of simple methods for the estimation of free testosterone in serum," The Journal of Clinical Endocrinology and Metabolism, vol. 84, no. 10, pp. 3666-3672, 1999.

[26] D. R. Matthews, J. P. Hosker, A. S. Rudenski, B. A. Naylor, D. F. Treacher, and R. C. Turner, "Homeostasis model assessment: insulin resistance and beta-cell function from fasting plasma glucose and insulin concentrations in man," Diabetologia, vol. 28, no. 7, pp. 412-419, 1985.

[27] M. Matsuda and R. A. DeFronzo, "Insulin sensitivity indices obtained from oral glucose tolerance testing: comparison with the euglycemic insulin clamp," Diabetes Care, vol. 22, no. 9, pp. 1462-1470, 1999.

[28] Z. Fu, F. Yao, A. B. Abou-Samra, and R. Zhang, "Lipasin, thermoregulated in brown fat, is a novel but atypical member of the angiopoietin-like protein family," Biochemical Biophysical Research Communications, vol. 430, no. 3, pp. 1126-1131, 2013.

[29] Z. Fu, F. Berhane, A. Fite, B. Seyoum, A. B. Abou-Samra, and R. Zhang, "Elevated circulating lipasin/betatrophin in human type 2 diabetes and obesity," Scientific Reports, vol. 4, p. 5013, 2014.

[30] M. Calan, O. Yilmaz, T. Kume et al., "Elevated circulating levels of betatrophin are associated with polycystic ovary syndrome," Endocrine, vol. 53, no. 1, pp. 271-279, 2016.

[31] Q. Qu, D. Zhao, F. Zhang, H. Bao, and Q. Yang, "Serum betatrophin levels are increased and associated with insulin resistance in patients with polycystic ovary syndrome," Journal of International Medical Research, vol. 45, no. 1, pp. 193-202, 2017.

[32] G. Sahin Ersoy, T. Altun Ensari, D. Vatansever, V. Emirdar, and O. Cevik, "Novel adipokines WISP1 and betatrophin in PCOS: relationship to AMH levels, atherogenic and metabolic profile," Gynecological Endocrinology, vol. 33, no. 2, pp. 119123,2017

[33] O. Erol, M. K. Özel, H. Y. Ellidağ, T. Toptaş, A. U. Derbent, and N. Yllmaz, "Assessment of circulating betatrophin concentrations in lean glucose-tolerant women with polycystic ovary syndrome," Journal of Obstetrics and Gynaecology, pp. 1-6, 2017.

[34] S. Song, J. Wang, C. Guo, and T. Jiang, "Elevated serum levels of betatrophin in patients with polycystic ovary syndrome and the influential factors," Zhong Nan Da Xue Xue Bao Yi Xue Ban, vol. 41, no. 9, pp. 969-974, 2016.

[35] L. Li, F. Zhang, J. Cui et al., "Association of betatrophin with metabolic characteristics in overweight/obese and lean women with PCOS," Gynecological Endocrinology, vol. 33, no. 3, pp. 238-243, 2017.

[36] G. Erbag, M. Eroglu, H. Turkon et al., "Relationship between betatrophin levels and metabolic parameters in patients with polycystic ovary syndrome," Cellular and Molecular Biology (Noisy-le-grand, France), vol. 62, no. 5, pp. 20-24, 2016. 


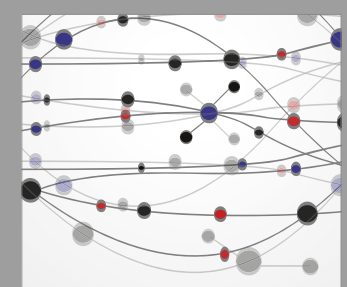

The Scientific World Journal
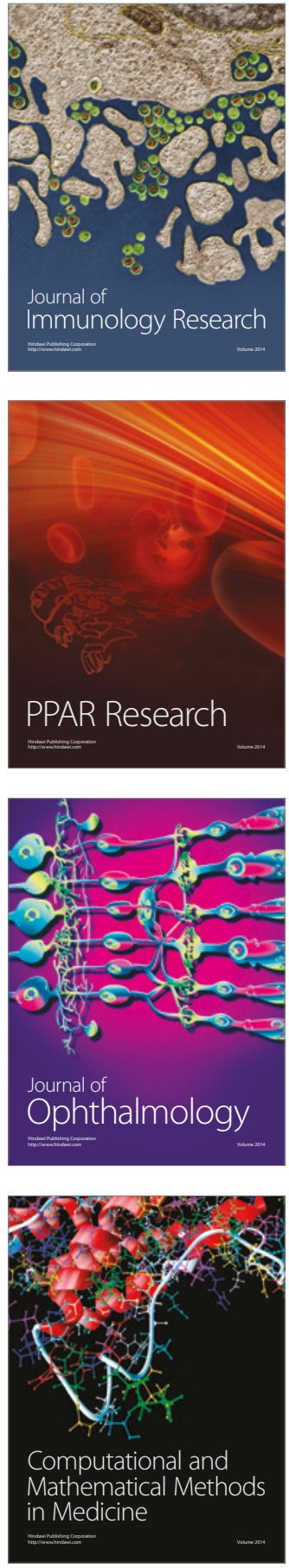

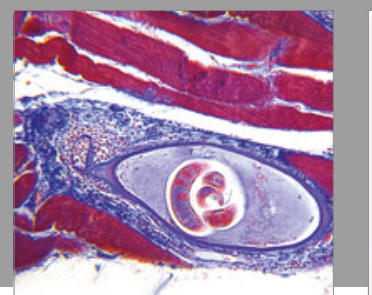

Gastroenterology Research and Practice
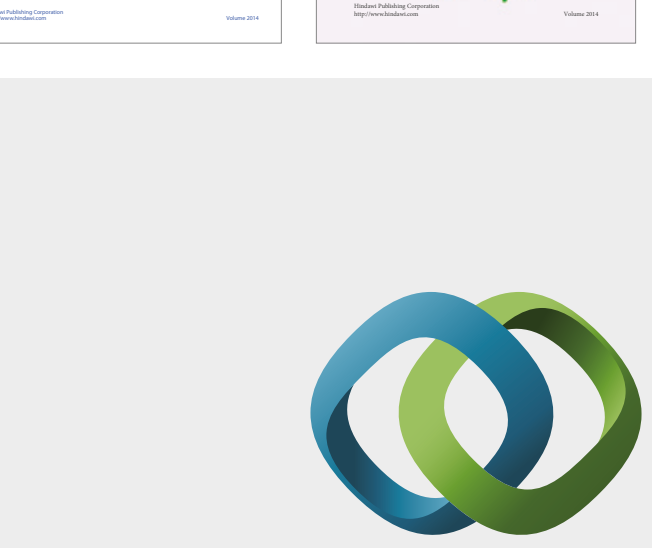

\section{Hindawi}

Submit your manuscripts at

https://www.hindawi.com
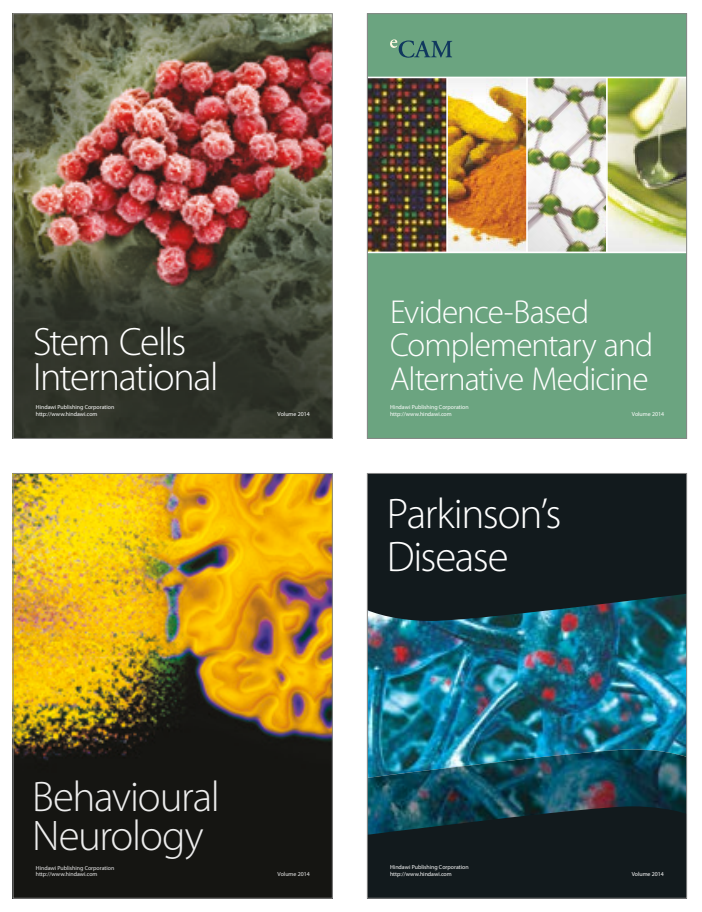
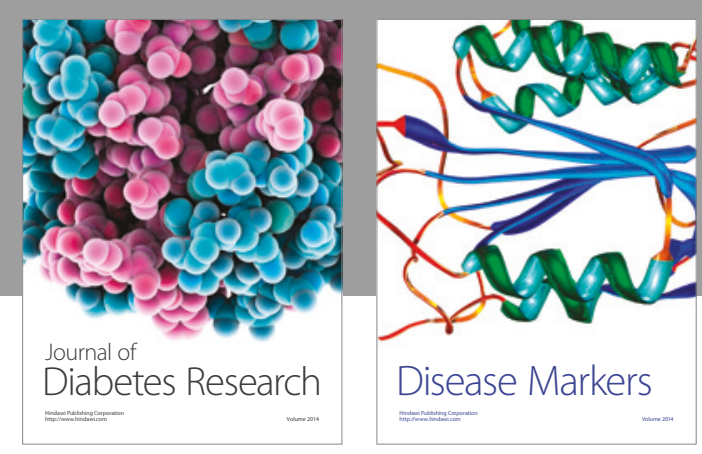

Disease Markers
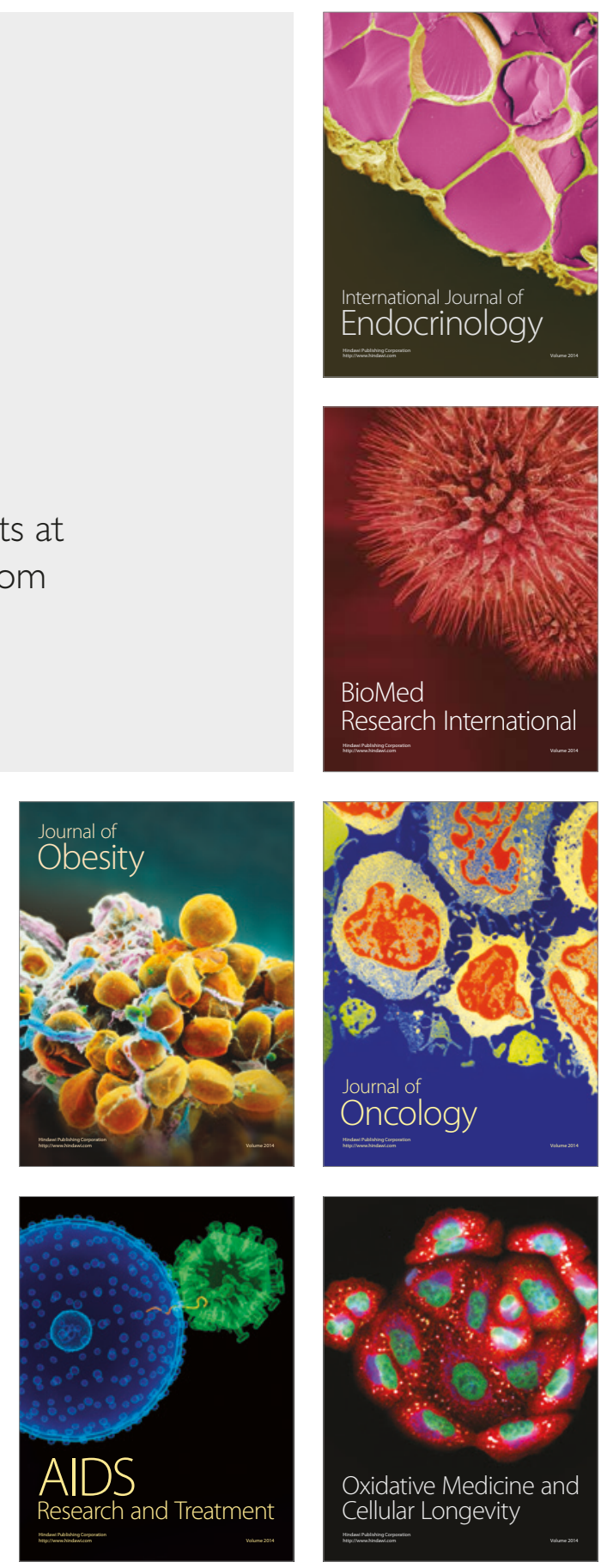